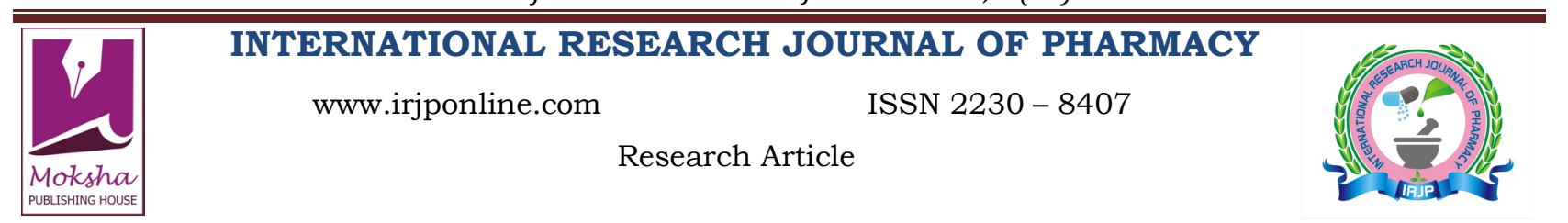

\title{
STUDY ON EXTRACTS OF PARMELIA PERLATA ACH. FOR ITS ANTIMICROBIAL POTENTIAL AGAINST CERTAIN MICROORGANISMS
}

Rauf Abdur $^{1 *}$, Latif Abdul ${ }^{2}$, Rehman Sumbul ${ }^{3}$ and Afaq S.H ${ }^{4}$

${ }^{1}$ Assistant Professor, Department of Ilmul Advia, F/o Unani Medicine; Aligarh Muslim University, Aligarh (U.P) India

${ }^{2}$ Associate Professor, Department of Ilmul Advia, F/o Unani Medicine; Aligarh Muslim University, Aligarh (U.P) India

${ }^{3}$ Project Fellow DRS-I (UGC), Department of Ilmul Advia, F/o Unani Medicine, Aligarh Muslim University, Aligarh (U.P)

India

${ }^{4}$ Professor, Department of Ilmul Advia, F/o Unani Medicine; Aligarh Muslim University, Aligarh (U.P) India

*Corresponding Author Email: abdurraufmd@yahoo.com

Article Received on: 30/09/13 Revised on: 21/10/13 Approved for publication: 30/10/13

DOI: 10.7897/2230-8407.041123

IRJP is an official publication of Moksha Publishing House. Website: www.mokshaph.com

(C) All rights reserved.

\section{ABSTRACT}

A significant increase in the trend of infectious diseases and alarming shoot up of resistance to existing antimicrobial agents demands a renewed effort to seek agents effective against pathogenic bacteria resistant to current antimicrobials. Different extracts of Parmelia perlata (Chhadela), were studied for their screening of antibacterial activity against various bacterial strains by Agar well diffusion method on inoculated Media plates. It was found that $P$. perlata has a significant activity towards Bacillus cereus, Pseudomonas aeruginosa and Proteus vulgaris, Staphylococcus aureus, Corynebacterium xerosis, Escherichia coli and Klebseilla pneuomoniae while no activity towards S. epidermidis, S. mutans and S. pyrogenes. Moreover it was seen that $50 \%$ hydro-ethanolic extracts produced more significant ZOI than $90 \%$ ethanolic extract in all tested strains. The antibacterial activity so found, can be due to the presence of chemical constituents as Usnic acid which can halt infection and is effective against various gram-positive and gram-negative bacteria species. It can be concluded that due to their antimicrobial effects, extracts of the lichen can be used for the infectious diseases caused by these microbes. This study provides an in-vitro proof of the antibacterial activity of Parmelia perlata.

Keywords: Parmelia perlata, Zone of Inhibition, Antibacterial efficacy.

\section{INTRODUCTION}

The increase in prevalence of new emerging infectious diseases has directed to amplify the development of new antimicrobial from alternative sources; phyto-chemicals from medicinal plants have the potential of filling this need. Screening of various bioactive compounds from plants has lead to the discovery of new medicinal drug which have efficient protection and treatment roles in against various diseases $^{1}$. The rapid emergence of multiple drug resistant strains of pathogens to current antimicrobial agents has generated an urgent intensive for new antibiotics from medicinal plants. Many medicinal plants have been screened extensively for their antimicrobial potential worldwide ${ }^{2-5}$. Parmelia perlata Ach. (Chhadela) is lichen that belongs to the family Parmeliaceae. It is known in Unani medicine as 'Hazaz-al-Sakhr' and 'Dowala' and used to cure many health ailments. It grows on old trees and walls and on rocks, distributed in Punjab and Himalayan regions, India. It is also available in Persia and Europe ${ }^{6-12}$. Parmelia perlata is the thallus, foliaceous, membranous leaf like horizontally spreading lobed and stellated structure more or less fibrous beneath, fixed only by a central point. The thallus is dirty white or grayish brown nearly $5-10 \mathrm{~cm}$ long, the surface is rugous and marked with irregular depressions. It is aromatic and mucilaginous, bitter or saline in taste $7,10,13,14$. Chhadela is reported in Unani literatures as astringent, antiemetic, antidote, analgesic, cardiotonic, emmenagogue, lactagogue and wound healing agent ${ }^{13-20}$. Ghani $(1921)^{21}$ while giving reference to Vedas mentioned that 'Chhadela' is useful in jaundice, indigestion, fevers, rabies and diseases of lungs. Its smokes relieve the headache, heal the wounds, increase flow of menses and relieve the pain of liver, uterus and stomach. The drug contains atronin (1.5\%), usnic acid $(0.3 \%)$, salazinic acid (3.8\%), lecanoric acid and protolichesteric acid $^{6,7}$. Usnic acid inhibits gram positive bacteria such as Streptococcus, Staphylococcus pneuomoniae in adults and a related organism Streptococcus pyogenes which is responsible for clinical conditions of pharyngitis that is commonly referred as Strap throat. Recently usnic acid has been tested for positivity as anti tumor agent ${ }^{21}$. Keeping in view of Usnic acid and other components in Chhadela an antibacterial study of the extracts of crude drug was carried out against various gram positive and gram negative bacterial strains.

\section{MATERIAL AND METHODS \\ Plant collection}

Parmelia perlata, (Figure 1) the whole herb was procured from the Baradari market of Aligarh, U.P (India) during summer (August) 2010 and was authenticated by the Department of Botany, Aligarh Muslim University, Aligarh, India and also with the available literature. Sample of the test drug was kept in museum, Department of Ilmul Advia, AMU, Aligarh, India for future references (Voucher No. SC0131/12) 


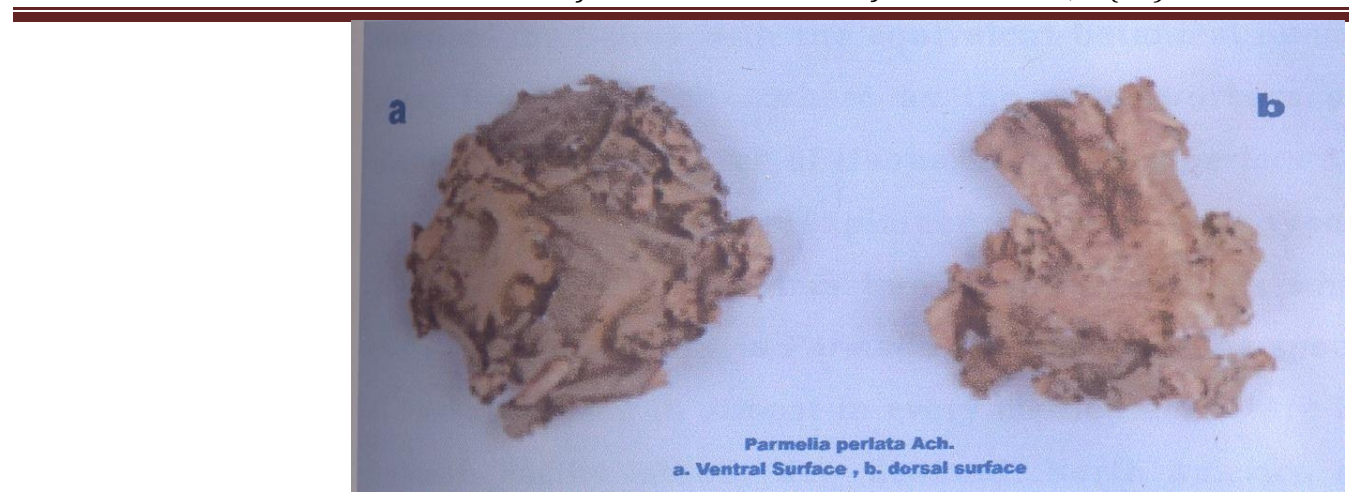

Figure 1: Parmelia perlata Ventral and Dorsal Surface

\section{Preparation of plant extracts}

The test drug was dried at room temperature in a ventilated room, milled to a fine powder and stored in a closed container in dark.

\section{$50 \%$ Hydro ethanolic extract}

$10 \mathrm{~g}$ of the powder of crude drug was refluxed with $150 \mathrm{ml}$ of $50 \%$ alcohol. The solvent was heated at $40^{\circ} \mathrm{C}$ and refluxed for a period of 150 minutes. The extract was filtered and evaporated to dryness under reduced pressure in the Lyophilizer (Macro Scientific, Delhi, India). For experiment, extract was re dissolved in Dimethyl Sulphoxide (DMSO) to the desired concentration.

\section{$90 \%$ ethanolic extract}

$10 \mathrm{~g}$ of crude drug powder and $150 \mathrm{ml}$ of $90 \%$ ethanol were put into a soxhlet apparatus. The solvent was heated at $40^{\circ} \mathrm{C}$ and refluxed for a period of 150 minutes. The extract was filtered and evaporated to dryness under reduced pressure in the Lyophilizer (Macro Scientific, Delhi, India). For experiment, extract was re dissolved in DMSO to the desired concentration.

\section{Test microorganisms}

Ten bacterial strains (six gram positive and four gram negative) were selected on the basis of their clinical importance. These strains were obtained from Hi-media Labs Pvt. Ltd., Mumbai, India and Microbial Type Culture Collection, Chandigarh, India. The selected strains were Staphylococcus aureus (ATCC 29213), Streptococcus mutans (ATCC 25175), Streptococcus pyrogenes (MTCC 435), Staphylococcus epidermidis (MTCC 435), Bacillus cereus (MTCC 430), Corynebacterium xerosis (ATCC 373), Escherichia coli (ATCC 25922), Klebsiella pneuomoniae (MTCC 109), Proteus vulgaris (MTCC 426) and Pseudomonas aeruginosa (MTCC 424). These strains were screened for evaluation of antibacterial activities of the Parmelia perlata.

\section{Medium}

The solid media namely Nutrient Agar No.2 (M 1269S-500G, Himedia Labs) was used for preparing nutrient plates, while Nutrient Broth (M002-500G, Himedia Labs) was used for the liquid culture media.

\section{In-vitro Antibacterial Activity Primary screening}

The antibacterial activities of the Parmelia perlata were evaluated by agar well diffusion method ${ }^{22}$. All the microbial cultures were adjusted to $0.5 \mathrm{Mc}$ Farland standards, which is visually comparable to a microbial suspension of approximately $1.5 \times 10^{8} \mathrm{cfu} / \mathrm{ml} .20 \mathrm{ml}$ of agar media was poured into each Petri plate and plates were swabbed with a colony from the inoculums of the test microorganisms and kept for 15 minutes for adsorption. Using sterile cork borer of $6 \mathrm{~mm}$ diameter, wells were bored into the seeded agar plates and these were loaded with a $50 \mu \mathrm{l}$ volume with concentration of $10 \mathrm{mg} / \mathrm{ml}$ of each compound reconstituted in the dimethylsulphoxide (DMSO). All the plates were incubated at $37^{\circ} \mathrm{C}$ for $24 \mathrm{~h}$. Antimicrobial activity of all the extracts of Parmelia perlata was evaluated by measuring the zone of inhibition against the test microorganisms with Antibiotic Zone Scale (PW297, Himedia Labs), which was holded over the back of the inverted plate. The plates were held a few inches above a black, non reflecting background and illuminated with reflected light. The medium with DMSO as solvent was used as a negative control, whereas, media with Ciprofloxacin (standard antibiotic for gram positive) and Gentamicin (standard antibiotic for gram negative) were used as positive control. The experiments were performed in triplicates.

\section{Determination of minimum inhibitory concentration (MIC)}

Minimum inhibitory concentration (MIC) is the lowest concentration of an antimicrobial compounds that will inhibit the visible growth of microorganisms after overnight incubation. Minimum inhibitory concentrations are important in diagnostic laboratories to confirm resistance of microorganisms to antimicrobial agents and also to monitor the activity of new antimicrobial agents. The MIC of the Parmelia perlata (Chhadela) was tested against bacterial strains through a broth dilution method. In this method, the test concentrations of extracts of 'Chhadela' were made from 2.5 to $0.01 \mathrm{mg} / \mathrm{ml}$ in the sterile wells of the micro-titer plates $^{23}$.

\section{Broth Dilution Method}

In a sterile microtitre plates (96-u-shaped wells) $50 \mu \mathrm{l}$ of the sterile nutrient broth was poured in each well in three rows, then from a fresh inoculums so formed $\left(10^{8} \mathrm{cfu} / \mathrm{ml}\right.$ diluted with $100 \mu \mathrm{l}$ Nutrient broth to have $\left.10^{6} \mathrm{cfu} / \mathrm{ml}\right) .50 \mu \mathrm{l}$ of the suspension was poured in each well in the first and third row, second row was again filled with $50 \mu$ of Nutrient broth, finally the drug sample $50 \mu \mathrm{l}$ was added in the first row diluting uniformly from 2.5 to $0.01 \mathrm{mg} / \mathrm{ml}$ till the $8^{\text {th }}$ well. MIC was expressed as the lowest dilution, which inhibited the growth judged by lack of turbidity in the well. All the 
microtitre plates were wrapped properly with a sterilized foil and incubated at $37^{\circ} \mathrm{C}$ for $18-24$ hours.

\section{RESULTS}

Parmelia perlata (Chhadela) contains a yellow pigment usnic acid in its cortex, and this acid is disrupting the metabolic functions of bacteria and finally kills as reported by Brodo, $1984^{24}$. Extracts of Parmelia perlata showed a wide range of antibacterial activity against Gram positive and Gram negative bacteria. Significant effect was noted towards $B$. cereus (Table 1), where as hydro-ethanolic extract of test drug produces a large ZOI of $23.33 \pm 0.33$ as compared to its
$90 \%$ ethanolic extract ZOI $-22.33 \pm 0.33$ (MIC-0.312 $\mathrm{mg} / \mathrm{ml}$ ) while the Standard drug Ciprofloxacin produces ZOIof $23 \mathrm{~mm}$. Against C. xerosis also hydro-ethanolic extract produces a moderate antibacterial effect ZOI of $14.33 \pm 0.33$ $\mathrm{mm}$ as compared to ethanolic extract ZOI of $13.33 \pm 0.33$ $\mathrm{mm}$ (MIC-5.0 $\mathrm{mg} / \mathrm{ml}$ ) but it was lower than ZOI by Ciprofloxacin $21 \mathrm{~mm}$. Similarly in $S$. aureus a moderate effect by extract was shown ZOI of $13.33 \pm 0.33$ by hydro ethanolic and $12.6 \pm 0.33 \mathrm{~mm}$ by ethanolic extract (MIC-2.5 $\mathrm{mg} / \mathrm{ml}$ ) which was lower than Standard drug ZOI $22 \mathrm{~mm}$. There was no activity seen towards $S$. epidermidis, $S$. mutans and $S$. pyrogenes by either extract (Table 1; Figure 2).

Table 1: Zone of Inhibition (in mm) of Parmelia perlata (Chhadela) against Gram-positive bacterial strains

\begin{tabular}{|c|c|c|c|c|c|}
\hline \multirow[t]{2}{*}{ S. No. } & \multirow[t]{2}{*}{ Strains } & \multicolumn{2}{|c|}{ Lichen } & \multirow{2}{*}{$\begin{array}{l}\text { Plane Control } \\
\text { DMSO }(40 \mu \mathrm{I})\end{array}$} & \multirow{2}{*}{$\begin{array}{c}\text { Standard Control } \\
\text { Ciprofloxacin }(30 \mu \mathrm{g} / \text { disk })\end{array}$} \\
\hline & & $50 \%$ Hydro-ethanolic extract & $90 \%$ ethanolic extract & & \\
\hline 1. & $\begin{array}{c}\text { S. aureus } \\
\text { (ATCC 29213) }\end{array}$ & $13.33 \pm 0.33 *$ & $12.6 \pm 0.33 *$ & - & $22 *$ \\
\hline 2. & $\begin{array}{c}\text { S. mutans } \\
\text { (ATCC 25175) }\end{array}$ & $12.6 \pm 0.33 *$ & - & - & $21 *$ \\
\hline 3. & $\begin{array}{l}\text { S. epidermidis } \\
\text { (ATCC 155) }\end{array}$ & - & - & - & $23 *$ \\
\hline 4. & $\begin{array}{c}\text { S. pyrogenes } \\
\text { (ATCC 14289) }\end{array}$ & - & - & - & $22 *$ \\
\hline 5 . & $\begin{array}{c}\text { B. cereus } \\
\text { (ATCC } 11778 \text { ) }\end{array}$ & $23.33 \pm 0.33 *$ & $22.3 \pm 0.33 *$ & - & $21 *$ \\
\hline 6. & $\begin{array}{c}\text { C. xerosis } \\
\text { (ATCC 373) }\end{array}$ & $12.66 \pm 0.33 *$ & - & - & $23^{*}$ \\
\hline
\end{tabular}

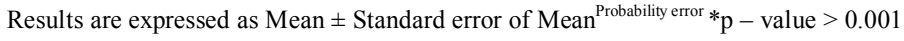

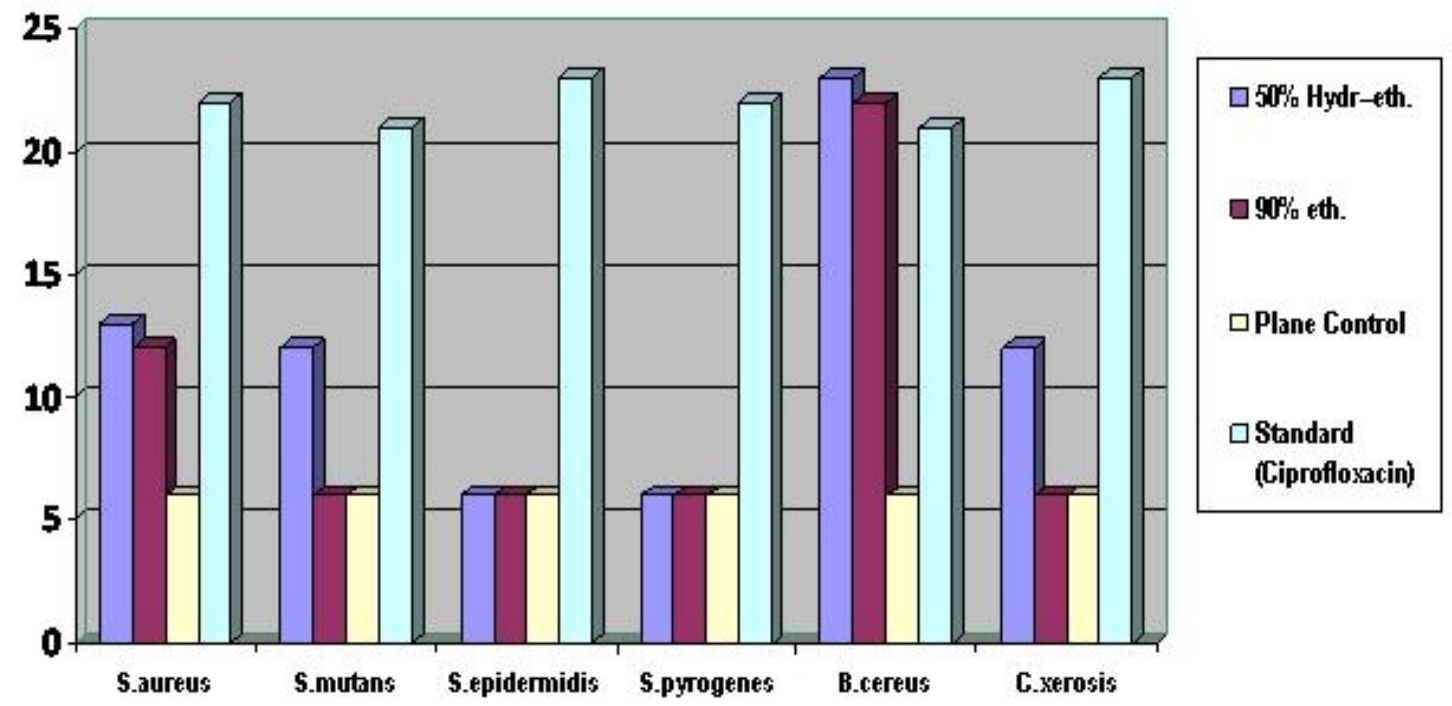

Figure 2: Zone of Inhibition (in mm) of different extracts of Parmelia perlata (Chhadela) against gram positive bacterial strains

Among the Gram negative strains (Table 2) of bacteria selected for the study, a significant activity was seen towards $P$. aeruginosa where test drug hydro ethanolic extract produced ZOI of $27.33 \pm 0.33 \mathrm{~mm}$ and ethanolic extract produces ZOI of $20.33 \pm 0.33 \mathrm{~mm}$ (MIC- $1.25 \mathrm{mg} / \mathrm{ml}$ ) which was much greater than ZOI produced by the Standard drug used- Gentamicin ZOI of $14 \mathrm{~mm}$, antibacterial activity towards $P$. vulgaris was also more as compared to Gentamicin where hydro ethanolic extract produced ZOI of $16.66 \pm 0.33$ and ethanolic extract of $13 \pm 0.57 \mathrm{~mm}$ (MIC-2.5 $\mathrm{mg} / \mathrm{ml}$ ) and Gentamicin ZOI was $14 \mathrm{~mm}$. There was also a considerable activity towards $E$. coli where hydro ethanolic extract ZOI was $14.33 \pm 0.33 \mathrm{~mm}$ and ethanolic extract as $11.33 \pm 0.33 \mathrm{~mm}$ (MIC-5.0 $\mathrm{mg} / \mathrm{ml}$ ) which was lower than ZOI by Gentamicin $15 \mathrm{~mm}$ and same was seen towards $K$. pneuomoniae where ZOI by test drug hydro ethanolic extract was $13.33 \pm 0.33 \mathrm{~mm}$ and by ethanolic extract was $11.33 \pm$ $0.33 \mathrm{~mm}$ (MIC-5.0 $\mathrm{mg} / \mathrm{ml}$ ) which was also lower than Gentamicin ZOI $15 \mathrm{~mm}$ (Table 2; Figure 3) 
Rauf Abdur et al. Int. Res. J. Pharm. 2013, 4 (11)

Table 2: Zone of Inhibition (in mm) of Parmelia perlata (Chhadela) against Gram-negative bacterial strains

\begin{tabular}{|c|c|c|c|c|c|}
\hline \multirow[t]{2}{*}{ S. No } & \multirow[t]{2}{*}{ Strains } & \multicolumn{2}{|c|}{ Lichen } & \multirow{2}{*}{$\begin{array}{c}\text { Plane Control } \\
\text { DMSO } \\
(40 \mu \mathrm{l})\end{array}$} & \multirow{2}{*}{$\begin{array}{c}\text { Standard Control } \\
\text { Gentamicin (30 } \\
\mu \mathrm{g} / \mathrm{disk})\end{array}$} \\
\hline & & $\begin{array}{c}50 \% \text { Hydro- } \\
\text { ethanolic extract }\end{array}$ & $\begin{array}{c}90 \% \text { ethanolic } \\
\text { extract }\end{array}$ & & \\
\hline 1. & E. coli (ATCC 25922) & $11.33 \pm 0.33 *$ & $13.33 \pm 0.33 *$ & - & $15^{*}$ \\
\hline 3. & P. aeruginosa (ATCC 25619) & $25.3 \pm 0.33 *$ & $27.3 \pm 0.33 * *$ & - & $14 *$ \\
\hline 4. & P. vulgaris (ATCC 6380) & $13.33 \pm 0.33 *$ & $13.33 \pm 0.33 *$ & - & $15^{*}$ \\
\hline
\end{tabular}

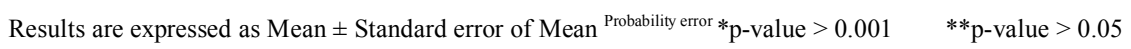

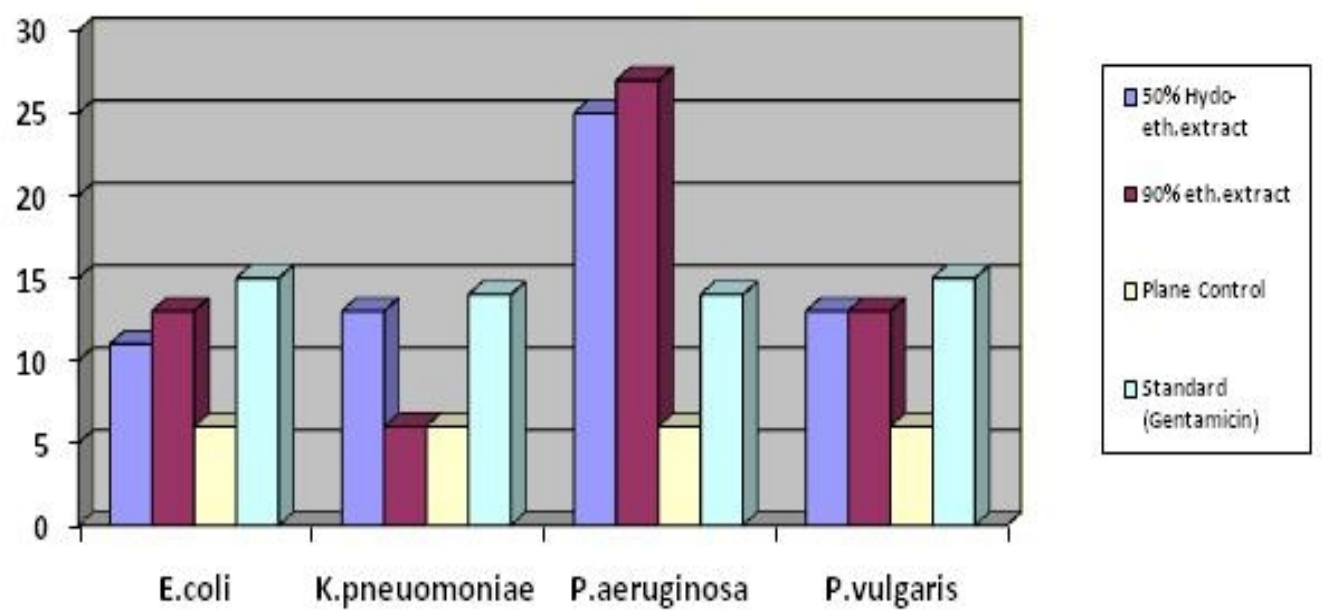

Figure 3: Zone of Inhibition (in mm) of different extracts of Parmelia perlata (Chhadela) against gram negative bacterial strains

While comparing the hydro-ethanolic and alcoholic extract in general it was noted that $50 \%$ hydro-ethanolic extract has more antibacterial effect as compared to $90 \%$ ethanolic extract (Table 3).

Table 3: Minimum Inhibitory Concentration of the Parmelia perlata (Chhadela) (mg/ml)

\begin{tabular}{|c|c|c|c|}
\hline S. No. & Strains & $\mathbf{5 0} \%$ Hydro-ethanolic extract & 90 \% Ethanolic extract \\
\hline 1. & S. aureus & 1.250 & $>5.00$ \\
\hline 2. & S. mutans & $>5.00$ & $>5.00$ \\
\hline 3. & S. epidermidis & $>5.00$ & $>5.00$ \\
\hline 4. & S. pyrogenes & $>5.00$ & $>5.00$ \\
\hline 5. & B. cereus & 0.312 & $>.625$ \\
\hline 6. & C. xerosis & 1.250 & 1.250 \\
\hline 7. & E. coli & 2.50 & $>5.00$ \\
\hline 8. & K. pneuomoniae & 1.250 & 0.156 \\
\hline 9. & P. aeruginosa & 0.625 & 2.500 \\
\hline 10. & P. vulgaris & 1.250 & \\
\hline
\end{tabular}

\section{DISCUSSION}

In recent years, the search from sources of natural origin possessing antimicrobial properties have been on the rise due to their potential use in the therapy of various chronic and infectious diseases. Due to the risk of adverse effects encountered with the use of synthetic antibiotics, medicinal plants may offer an alternative source for antimicrobial agent with significant activity against pathogenic and infective microorganisms. In addition, a number of antibiotics have lost their effectiveness due to the development of resistant strains, mostly through the expression of resistance genes. Present study findings confirmed the use of Parmelia perlata in infectious diseases. We found strong antimicrobial activities in the hydro-ethanolic and ethanolic extracts of Parmelia perlata against all Gram-positive and Gram negative bacteria tested. This medicinal plant by in vitro results appear as interesting and promising and may be effective as potential sources of novel antimicrobial drug.

\section{CONCLUSION}

The study concludes that 'Chhadela' has a potent antibacterial activity against various pathogenic bacteria. Parmelia perlata (Chhadela) contains a yellow pigment usnic acid in its cortex, and this acid is disrupting the metabolic functions of bacteria and finally kills, therefore the antibacterial activity of Parmelia perlata is justified. This drug can be used to drive antimicrobial agents to fight against the number of infectious diseases mainly against $B$. cereus, $P$. vulgaris and $P$. aeruginosa, after exploring other pharmacological details.

\section{ACKNOWLEDGEMENT}

Authors are highly thankful to DRS-I (UGC) of Department of Ilmul Advia for providing assistance during the study.

\section{REFERENCES}

1. Govindappa M, Sadananda TS, Channabasava R, Jeevitha MK, Pooja KS and Vinay B Raghavendra. Antimicrobial, Antioxidant Activity and Phytochemical Screening of Tecoma Stans (L.) Juss. Ex Kunth Journal of Phytology Phytopharmacology 2011; 3(3): 68-76. 
2. Ahmad N, Khan MI, Ahmed S, Faisal M, Anis M, Rehman S, Umair SM. Change in total phenolic content and antibacterial activity in regenerates of Vitex negundo L. Biologia planatarum 2013; 35(3),2: 791-800.

3. Rehman S, Latif A, Ahmad S, Khan AU. In-vitro antibacterial screening of Swertia chirayita Linn. against some gram negative pathogenic strains. International Journal of Pharmaceutical Research and Development 2012; 4(04): 188-194.

4. Rahman A, Tajuddin, Amin KMY and Rehman S. Antimicrobial assay of alcoholic and hydroalcoholic extract of a Unani formulation by Agar well method. Hippocratic Journal of Unani Medicine 2013; 8(1): 59-66.

5. Rehman S, Latif A, Ahmad S, Khan AU. Antibacterial Screening of Fumaria officinales Linn. A Drug of choice. Journal of Integrated Community Health 2013; 1(2): 61-67.

6. Chopra GL. A text book of Fungi. $14^{\text {th }}$ ed. SL Jain, Fors. Nagin and Co., Partab Road, Jullundur city; 1979. p. 350-354.

7. Rastogi RP, Mehrotra BN. Compendium of Indian Medicinal Plants. Pub. Central Drug Research Institute Lucknow and National Institute of Science Communication, New Delhi; 1999. p. 425.

8. Dymock W, Warden CJH and Hooper D. Pharmacographica Indica. The Institute of Health and Tibbi Research Hamdard National Foundation. Pakistan; 1972. p. 627-628.

9. Nadkarni KM. Indian Materia Medica. Ed.3. Pub. Popular Parkashan Pvt. Ltd. Bombay; 1982. p. 922.

10. Khory RN and Katrak NN. Materia Medica of India and Their Therapeutics. Pub. Neeraj Publishing House. New Delhi; 1985. p. 652653.

11. Kiritikar KR and Basu BD. Indian Medicinal Plants. Ed. 3. Pub. Lalit Mohan Basu MB. Allahabad; 1996. p. 2757.

12. Pandey BP. Text Book of Botany- the Fungi. Ed. 3. Pub. K Nath and Co. Educational Publishers. Meerut; 1973. p. 229-232.
13. Lindley J. The Flora Medica. Pub. Ajay Book Service. New Delhi; 1981. p. 625 .

14. Husain MM. Makhzanul Advia ma Tohfatul Momineen. Pub. Matba Munshi Nawal Kishore. Lucknow; 1874. p. 86.

15. Attar HZA. Ikhtiyarat-e- Badiye. Pub. Matba Munshi Nawal Kishore. Lucknow; 1888. p. 25-26.

16. Ibn Sina HBA. Al Qanoon fit Tib. Pub. Matba Munshi Nawal Kishore. Lucknow; 1931. p. 39.

17. Razi MBZ. Al Hawi fit Tib. Pub. Majlis Dairatul Maarif. Hyderabad; 1967. p. 9-11.

18. Azam M. Muheet Azam. Pub. Matba Nizami. Kanpur; 1987. p. 163-164.

19. Baitar ZI. Al-Jamey li Mufradat al Advia wal Aghzia. Pub. Central Council for research in Unani Medicine. New Delhi; 1986. p. 80-82.

20. Majoosi ABA. Kamil-al Sanaa. Pub. Matba Kubra. Egypt; 1869. p. 108.

21. Ghani N. Khazainul Advia. Pub. Matba Munshi Nawal Kishore. Lucknow; 1921. p. 143-144.

22. Anonymous. National Committee for Clinical Laboratory Standards (NCCLS), Methods for Disks Susceptibility Tests for bacteria that grow aerobically, NCCLS, Approved Standards Sixth edition-NCCLS document M2-A7, Wayne, USA; 2000. p. 7.

23. Andrews JM. Determination of Minimum Inhibitory Concentrations. Journal of Antimicrobial Chemotherapy Suppl.SI 2001; 48: 5-16.

24. Brodo IM. Lichens Canadensis Exsiccate Fascicle. Bryologist; 1984. p. 111.

\section{Cite this article as:}

Rauf Abdur, Latif Abdul, Rehman Sumbul and Afaq S.H. Study on extracts of Parmelia perlata Ach. for its antimicrobial potential against certain microorganisms. Int. Res. J. Pharm. 2013; 4(11):102-106 http://dx. doi.org/10.7897/2230-8407.041123 